\title{
Tetranychus urticae (Acari: Tetranychidae) on Gerbera jamesonii Bolus and Hook (Asteraceae)
}

\author{
Silva, EA. ${ }^{\mathrm{a}}$, Reis, $P R .^{\mathrm{b} *}$, Carvalho, $T M B .^{\mathrm{c}}$ and Altoé, $B F^{\mathrm{c}}$

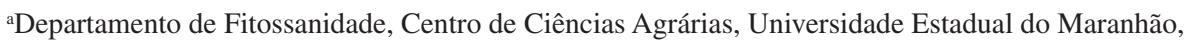 \\ CP 09, CEP 65055-310, São Luís, MA, Brazil

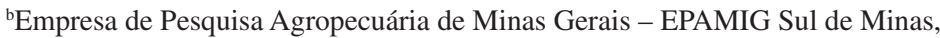 \\ EcoCentro, CP 176, CEP 37200-000, Lavras, MG, Brazil \\ ${ }^{\mathrm{c}}$ Universidade Federal de Lavras - UFLA, \\ CP 3037, CEP 37200-000, Lavras, MG, Brazil \\ *e-mail: paulo.rebelles@epamig.ufla.br
}

Received November 27, 2007 - Accepted June 12, 2008 - Distributed November 30, 2009

\begin{abstract}
Gerbera (Gerbera jamesonii Bolus and Hook,) is an ornamental Asteraceae of great commercial value, and pests can affect adversely its cultivation. More than 20 species of arthropods cause economic damage on gerbera, among them the two spotted mite, Tetranychus urticae Koch, 1836 (Acari: Tetranychidae), considered a key pest for this and other ornamental plants. In this work, some life-cycle aspects of T. urticae on gerbera, considered important for the knowledge of its population dynamics and for pest management programs, were studied. Mites were reared on 3-cm diameter arenas of gerbera leaf discs maintained on distilled water in Petri dishes, under laboratory conditions of $25{ }^{\circ} \mathrm{C}, 70 \pm 10 \% \mathrm{RU}$ and 14 -hour photophase, with only one egg left per arena, in a total of 262 arenas. Egg viability was $96.5 \%$ and $97.1 \%$ for unmated and mated females, respectively. Unmated females originated larvae which lived for 3.2 days and the stages of protonymph and deutonymph, 1.9 and 1.6 days, respectively; those from mated females lived 3.5 days and for protonymphs and deutonymphs, 2.0 and 1.6 days, respectively. Except for the duration of one generation (T), with similar values, 18.6 and 19.7 days, respectively for unmated and mated females, the net reproductive rate of increase $\left(\mathrm{R}_{0}\right)$, the innate capacity to increase in number $\left(\mathrm{r}_{\mathrm{m}}\right)$ and the finite rate of growth $(\lambda)$ were different for mated and unmated females, respectively 11.5 and 24.6 for $\mathrm{R}_{0 ;} 0.12$ and 0.17 for $\mathrm{r}_{\mathrm{m}}$ and 1.13 and 1.19 for $\lambda$.
\end{abstract}

Keywords: Gerbera, biology, fertility life table, two-spotted spider mite.

\section{Biologia de Tetranychus urticae (Acari: Tetranychidae) em Gerbera jamesonii Bolus and Hook (Asteraceae)}

\section{Resumo}

A gérbera, Gerbera jamesonii Bolus and Hook, é uma planta ornamental pertencente à família Asteraceae de grande valor comercial. Dentre os vários fatores que podem afetar adversamente o seu cultivo se encontram as pragas. Mais de 20 espécies de artrópodes causam danos econômicos em gérbera, entre elas encontra-se o ácaro-rajado, Tetranychus urticae Koch, 1836 (Acari: Tetranychidae), considerado praga-chave dessa e de outras plantas ornamentais. O presente trabalho teve por objetivo estudar alguns aspectos do ciclo biológico de T. urticae em gérbera considerados importantes para o conhecimento da dinâmica populacional da espécie e para os programas de manejo de pragas. Os ácaros foram criados em arenas constituídas de discos de folhas de gérbera de $3 \mathrm{~cm}$ de diâmetro, sobre água destilada, colocados em placas de Petri, em condições de laboratório, a $25^{\circ} \mathrm{C}, 70 \pm 10 \%$ de U.R. e 14 horas de fotofase, deixando-se um ovo por arena, perfazendo um total de 262 arenas. A viabilidade dos ovos foi de 96,5 e 97,1\% para fêmeas não acasaladas e acasaladas, respectivamente. As larvas provenientes de fêmeas não acasaladas tiveram duração de 3,2 dias e os estágios de protoninfa e deutoninfa foram de 1,9 e 1,6 dias, respectivamente. Já para fêmeas acasaladas a fase de larva teve uma duração de 3,5 dias, a de protoninfa e deutoninfa 2,0 e 1,6 dias, respectivamente. À exceção da duração de uma geração (T) que tiveram valores próximos, 18,6 e 19,7, respectivamente para fêmeas não acasaladas e acasaladas, a taxa líquida de reprodução $\left(\mathrm{R}_{0}\right)$, capacidade inata de aumentar em número $\left(\mathrm{r}_{\mathrm{m}}\right)$ e razão finita de crescimento $(\lambda)$ foram diferentes para fêmeas acasaladas e não, sendo respectivamente 11,5 e 24,6 para $R_{0}$; 0,12 e 0,17 para $r_{m}$ e 1,13 e 1,19 para $\lambda$.

Palavras-chave: gérbera, biologia, tabela de vida de fertilidade, ácaro-rajado. 


\section{Introduction}

Production of ornamental flowers combines economic returns with satisfaction to the grower, and has recently experienced expressive growth. Brazil has great potential to gain and keep international markets in ornamental flowers due to its diversity in soil and climate environments, which allows the growth of a large number of flower species of good quality and beauty, tropical flowers among others (Instituto Brasileiro de Floricultura, 2006).

Gerbera jamesonii Bolus and Hook, popularly known as gerbera or Transvaal daisy, is a herbaceous, Asteraceae (Compositae) that produces showy capitula of variable colors of high commercial value (Roriz and Cunha, 1998; Lorenzi and Souza, 2000). More than 20 species of arthropods are known to cause economic injury to gerbera and the two-spotted mite, Tetranychus urticae Koch, 1836 (Acari: Tetranychidae) is considered a key pest of this and other ornamental plants. Several pests are known to be resistant to one or more pesticides used in flower cultivation, including gerbera (Carne-Cavagnaro et al., 2005), T. urticae in some parts of the world (García-Marí and González-Zamora, 1999). This species feeds on the lower leaf surface, where it lives in colonies underneath a webbing structure that it produces. It sucks the cells content, turning leaves chlorotic; if the attack is continuous, leaves may fall and the number of flowers produced may be reduced considerably (Gallo et al., 2002). In addition to yield reduction, there may be a reduction in quality of the flowers produced (Karlik et al., 1995).

Shih et al. (1976) studying T. urticae on beans (Phaseolus vulgaris L.), found 2.3, 0.6, 0.4 and 1.9 days respectively for egg, larva, protonymph and deutonymph, and 7.6 and 5.6 days respectively for adult females and males. For fecundity, the mean number of eggs produced was 37.9, a daily deposition of 2.4 eggs per female. The mean longevity was of 19.1 days for females and 14.6 days for males. Reis et al. (2005) reported that the biological cycle from egg to adult is of approximately 10 days.

In biological studies of $T$. urticae on cotton (Gossypium hirsutum L.) cultivars, Silva et al. (1985) found a net reproductive rate $\left(\mathrm{R}_{0}\right)$ from 34.4 to 54.5 ; the mean duration of one generation (T) from 17.8 and 24.9 days, the innate capacity to growth in number $\left(r_{m}\right)$ from 0.161 to 0.207 and the finite rate of increase $(\lambda)$ from 1.172 to 1.230 . The number of eggs/female/day varied from $4.4 \pm 1.0$ to $7.7 \pm 0.8$.

Observations of Chahine and Michelakis (1994) of the longevity and fecundity of T. urticae females on several host plants demonstrated that longevity was of 10.7 days on egg plant (Solanum melongena L.), tomato (Lycopersicon esculentum Mill.) and beans (P. vulgaris), and 8.6 days on cucumber (Cucumeris sativus L.). The host plant influenced more fecundity than longevity, 71 eggs/female on egg plant and 55.2 on beans, both figures significantly different than those for cucumber (18.2) and tomato (10.6).

In spite of the economic importance of $T$. urticae for ornamental plants, no data were available in Brazil about its biology on several species, gerbera among them. Recognising the economic importance of T. urticae for the cultivation of ornamental plants, this work reports some biological parameters of this species on gerbera, and the construction of a fertility life table, considered important for the knowledge of population dynamics and for future programs of management of this pest.

\section{Material and Methods}

The study was conducted in the acarology laboratory of "Centro de Pesquisa em Manejo Ecológico de Pragas e Doenças de Plantas - EcoCentro, of the Empresa de Pesquisa Agropecuária de Minas Gerais - EPAMIG", in Lavras, in the state of Minas Gerais, Brazil. The experimental units were maintained at $25{ }^{\circ} \mathrm{C}, 70 \pm 10 \%$ R.H. and 14 hours photophase.

The stock population of T. urticae started with specimens colleted from gerbera plants purchased in the local market but produced in the city of Holambra, in the state of São Paulo. Rearing of T. urticae was made both in potted gerbera plants and in arenas in the laboratory. Gerbera 3-cm diameter leaf discs were placed on 22-cm diameter Petri dishes with moist polyethylene foam surrounded by wet hydrophilic cotton in distilled water to avoid escape of mites. For biological studies, females were carefully transferred from stock rearing to the arenas using a small brush. Only one female was placed on each rearing unit for oviposition, in a total of 262 arenas; after this period, females were removed and only one egg was maintained in each arena. Daily observations with a stereomicroscope were made at 7:00 AM and 3:00 PM during the incubation period up to the emergence of the larvae. The arenas were kept floating on the surface of distilled water contained in a $5-\mathrm{cm}$ diameter $\times 2 \mathrm{~cm}$ height Petri dish. To keep them in place, a hole was made in the centre of each leaf disk, trespassed by an upside down pin with the head fixed with silicone glue on dish bottom. Leaf disks served both as arena and feeding place for the mites, which were observed and replaced at the beginning of their withering, as detected in arenas where mites remained for longer periods in observation.

Daily observations continued to be at 7:00 AM and 3:00 PM after eclosion of the larvae, to determine the duration of the different stages of development. Each mite represented a replicate. After emergence of adults, males were confined individually for determination of their longevity, and females placed together with males from the stock rearing and replaced after death. Longevity and fecundity of both mated and non-mated females were daily observed. The sex ratio was determined after counting of males and females. Results obtained were submitted to the analysis of variance and means compared by the non-parametric method of Wilcoxon at $5 \%$ of signifi- 
cance. The fertility life table was calculated according to Silveira Neto et al. (1976).

\section{Results and Discussion}

\subsection{Development and reproduction of T. urticae}

Egg incubation period was of approximately 3.9 and 3.3 days, respectively for unmated and mated females (Table 1), and viability approximately the same for unmated and mated females, respectively 96.5 and $97.1 \%$ (Table 2), evidence of the good biotic potential of this species which guarantees a good number of offspring to perpetuate the species regardless of the presence of males. Laing (1969) reported more than 7 days for this period, possibly a result of factors like the type of host plant and temperature.

The development stage was longer for almost all mated females, with significant differences for the initial phases of larva, protochrysalid and protonymph, with no differences for the other stages (Table 1). Males had higher longevity (32.9 days) than unmated (15.7 days) and mated females (8.8 days) (Table 1). Both total female life cycle and longevity resulted from significant differences found in their developmental phases. Mated females showed shorter longevity (Table 1).

Shih et al. (1976) found lower values for all immature stages of T. urticae on beans, except 1.9 days for deutonymphs. According to Van de Vrie et al. (1972), the development rate for immature stages is influenced by several factors like temperature, humidity and food quality. The longevity results of this work differ from those of Shih et al. (1976) who reported 19.1 days for mated females. They also demonstrated that the host plant affected more fecundity than longevity. Chahine and Michelakis (1994) pointed out that no difference was found in longevity when egg plant, tomato and beans were used as hosts, but fecundity was indeed affected by the host plant. This indicates that the developmental

Table 1. Egg and post-embryonic stages duration time (days) of Tetranychus urticae Koch, 1836 on gerbera leaf at $25^{\circ} \mathrm{C}$, $70 \pm 10 \%$ R.H. and 14 hours of photophase.

\begin{tabular}{|c|c|c|c|c|c|}
\hline \multirow[t]{2}{*}{ Stage of development } & \multicolumn{2}{|c|}{ Non-mated females } & \multicolumn{2}{|c|}{ Mated females } & \multirow[t]{2}{*}{$\operatorname{Pr}>X^{2}$} \\
\hline & Period $(E P)^{1}$ & $\mathbf{N}^{2}$ & Period $(E P)^{1}$ & $\mathbf{N}$ & \\
\hline Egg & $3.90(0.05)$ & 110 & $3.15(0.09)$ & 238 & $0.006^{*}$ \\
\hline Larva & $3.24(0.21)$ & 72 & $3.46(0.11)$ & 123 & $0.0350 *$ \\
\hline Protochrysalid & $0.96(0.05)$ & 71 & $1.13(0.04)$ & 121 & $0.0001 *$ \\
\hline Protonymph & $1.86(0.13)$ & 57 & $2.10(0.08)$ & 94 & $0.0456^{*}$ \\
\hline Deutochrysalid & $1.17(0.09)$ & 57 & $1.07(0.03)$ & 80 & $0.2254^{\mathrm{ns}}$ \\
\hline Deutonymph & $1.57(0.09)$ & 55 & $1.63(0.07)$ & 65 & $0.1866^{\mathrm{ns}}$ \\
\hline Teleiochrysalid & $1.10(0.04)$ & 54 & $1.11(0.04)$ & 59 & $0.4710^{\mathrm{ns}}$ \\
\hline Adult female (longevity) & $15.72(1.18)$ & 32 & $8.83(1.03)$ & 27 & $<0.0001^{*}$ \\
\hline Adult male (longevity) & $32.88(4.84)$ & 27 & $14.19(2.71)$ & 27 & $0.0019 *$ \\
\hline Total cycle & $26.25(1.28)$ & 32 & $21.65(0.96)$ & 27 & $0.0063 *$ \\
\hline
\end{tabular}

${ }^{1}$ Mean \pm Standard error of the mean; ${ }^{2}$ Number of observations.

Significance of statistical comparison among means by the non-parametric test of Wilcoxon at $5 \%$.

Table 2. Duration in days of the periods of pre-oviposition, oviposition and post-oviposition; number of eggs per day, viability of eggs and longevity of Tetranychus urticae Koch, 1836 on leaves of gerbera, at $25^{\circ} \mathrm{C}, 70 \pm 10 \% \mathrm{RH}$ and 14 hours of photophase.

\begin{tabular}{|c|c|c|c|c|c|}
\hline \multirow[t]{2}{*}{ Characteristics } & \multicolumn{2}{|c|}{ Non mated females } & \multicolumn{2}{|c|}{ Mated females } & \multirow[t]{2}{*}{$\operatorname{Pr}>X^{2}$} \\
\hline & Period $(\mathrm{EP})^{1}$ & $\mathbf{N}^{2}$ & Period $(\mathrm{EP})^{1}$ & $\mathbf{N}^{2}$ & \\
\hline Pre-oviposition & $1.91(0.18)$ & 32 & $1.71(0.16)$ & 24 & $0.2418^{\mathrm{ns}}$ \\
\hline Oviposition & $11.47(0.92)$ & 32 & $6.21(0.98)$ & 24 & $<0.0001 *$ \\
\hline Post-oviposition & $1.44(0.44)$ & 32 & $1.21(0.32)$ & 24 & $0.3691^{\mathrm{ns}}$ \\
\hline No. eggs/female & $41.0(0.26)$ & 32 & $3.03(0.31)$ & 24 & $0.1099^{\text {ns }}$ \\
\hline No. eggs/female/day & $3.75(4.09)$ & 32 & $21.58(4.69)$ & 24 & $0.0002 *$ \\
\hline Egg viability & $96.5 \%$ & 114 & $97.1 \%$ & 245 & - \\
\hline
\end{tabular}

${ }^{1}$ Mean \pm Standard error of the mean; ${ }^{2}$ Number of observations; (-) no data

Significance of statistical comparison among means by the non-parametric test of Wilcoxon at $5 \%$. 
cycle of $T$. urticae is influenced by several factors and research in other ornamental plants hosting this species is in need, for the plant structure may influence pest development.

Laing (1969) found similar development time for males and females (16.1 and 16.9 days, respectively), different from what was reported here (Table 1). Van de Vrie et al. (1972) emphasised the occurrence of the differences between males and females as to development rate. Shih et al. (1976) reported lower values for longevity of females (19.1 days) and males (14.6 days), but according to Van de Vrie et al. (1972) specimens of different stages can vary considerably in relation to their exposure to environmental conditions.

On reproduction, non-mated females had longer mean oviposition period, with similar values for other parameters. The number of eggs/female/day was significantly higher for non- mated females (Table 2). Laing (1969) found lower values for oviposition compared to what was observed in this study for mated females, mean of $2.4 \mathrm{eggs} / \mathrm{female} / \mathrm{day}$. The influence of several factors to mites, temperature among others, may explain the

Table 3. Fertility life table of Tetranychus urticae Koch, 1836, on gerbera leaves at $25^{\circ} \mathrm{C}, 70 \pm 10 \%$ R.H. and 14 hours of photophase.

\begin{tabular}{|c|c|c|c|c|c|c|c|c|}
\hline \multicolumn{5}{|c|}{ Non-mated female } & \multicolumn{4}{|c|}{ Mated female } \\
\hline $\mathbf{X}^{1}$ & $\mathbf{M X}^{2}$ & $\mathbf{L X}^{3}$ & MX.LX & MX.LX.X & $\mathbf{M X}^{2}$ & $\mathbf{L X}^{\mathbf{3}}$ & MX.LX & MX.LX.X \\
\hline 12.5 & 0.018 & 1 & 0.018 & 0.23 & - & - & - & - \\
\hline 13.5 & 0.39 & 1 & 0.39 & 5.27 & - & - & - & - \\
\hline 14.5 & 1.995 & 1 & 1.995 & 28.9 & 0.19 & 1 & 0.19 & 2.76 \\
\hline 15.5 & 2.73 & 1 & 2.73 & 42.3 & 1.18 & 1 & 1.18 & 18.3 \\
\hline 16.5 & 4.097 & 1 & 4.097 & 67.6 & 1.67 & 1 & 1.67 & 27.6 \\
\hline 17.5 & 3.21 & 1 & 3.21 & 56.2 & 1.73 & 0.85 & 1.47 & 25.7 \\
\hline 18.5 & 3.14 & 0.97 & 3.05 & 56.4 & 1.94 & 0.67 & 1.3 & 24.05 \\
\hline 19.5 & 2.64 & 0.97 & 2.6 & 50.7 & 1.995 & 0.63 & 1.26 & 24.6 \\
\hline 20.5 & 1.96 & 0.91 & 1.8 & 36.9 & 1.82 & 0.59 & 1.07 & 21.94 \\
\hline 21.5 & 1.39 & 0.81 & 1.13 & 24.3 & 1.44 & 0.52 & 0.75 & 16.13 \\
\hline 22.5 & 1.25 & 0.72 & 0.9 & 20.3 & 1.48 & 0.52 & 0.77 & 17.3 \\
\hline 23.5 & 1.25 & 0.69 & 0.9 & 21.2 & 0.98 & 0.48 & 0.47 & 11.05 \\
\hline 24.5 & 0.93 & 0.59 & 0.5 & 12.3 & 1.14 & 0.48 & 0.55 & 13.5 \\
\hline 25.5 & 0.75 & 0.59 & 0.44 & 11.2 & 0.73 & 0.296 & 0.22 & 5.61 \\
\hline 26.5 & 0.43 & 0.53 & 0.23 & 6.095 & 0.46 & 0.296 & 0.14 & 3.7 \\
\hline 27.5 & 0.45 & 0.44 & 0.198 & 5.45 & 0.53 & 0.296 & 0.16 & 4.4 \\
\hline 28.5 & 0.29 & 0.44 & 0.13 & 3.7 & 0.398 & 0.15 & 0.06 & 1.7 \\
\hline 29.5 & 0.25 & 0.31 & 0.08 & 2.4 & 1.41 & 0.11 & 0.16 & 4.7 \\
\hline 30.5 & 0.11 & 0.31 & 0.03 & 0.9 & 0.53 & 0.11 & 0.06 & 1.8 \\
\hline 31.5 & 0.12 & 0.31 & 0.04 & 1.26 & 0.27 & 0.07 & 0.02 & 0.6 \\
\hline 32.5 & 0.09 & 0.28 & 0.03 & 0.98 & 0.27 & 0.07 & 0.019 & 0.62 \\
\hline 33.5 & 0.07 & 0.25 & 0.02 & 0.67 & 0.27 & 0.07 & 0.019 & 0.64 \\
\hline 34.5 & 0.05 & 0.25 & 0.013 & 0.45 & 0.0 & 0.07 & 0.0 & 0.0 \\
\hline 35.5 & 0.05 & 0.22 & 0.01 & 0.36 & - & - & - & - \\
\hline 36.5 & 0.05 & 0.19 & 0.0095 & 0.35 & - & - & - & - \\
\hline 37.5 & 0.04 & 0.19 & 0.008 & 0.3 & - & - & - & - \\
\hline 38.5 & 0.04 & 0.16 & 0.007 & 0.27 & - & - & - & - \\
\hline 39.5 & 0.04 & 0.16 & 0.007 & 0.28 & - & - & - & - \\
\hline 40.5 & 0.02 & 0.16 & 0.003 & 0.12 & - & - & - & - \\
\hline 41.5 & 0.02 & 0.13 & 0.003 & 0.125 & - & - & - & - \\
\hline 42.5 & 0.02 & 0.13 & 0.003 & 0.13 & - & - & - & - \\
\hline 43.5 & 0.02 & 0.13 & 0.003 & 0.13 & - & - & - & - \\
\hline 44.5 & 0.02 & 0.13 & 0.003 & 0.13 & - & - & - & - \\
\hline$\Sigma$ & - & - & 24.6 & 457.9 & - & - & 11.54 & 226.7 \\
\hline
\end{tabular}

$\mathrm{X}^{1}=$ mean time interval; $\mathrm{MX}^{2}=$ total eggs number/female/week; $\mathrm{LX}^{3}=$ survivalship probability in mean time. 
differences encountered by the authors. The biology of this tetranychid is subjected to influences of all sorts of alterations in rearing conditions, and temperature indeed causes variation in the total life cycle of T. urticae.

\subsection{Fertility life table}

The values of survival rate (lx) and specific fertility $(\mathrm{mx})$ of $T$. urticae in gerbera leaves are presented in Table 3. Higher indexes, except for generation duration (T), were observed to unmated as compared to mated females, with the increase finite rate $(\lambda)$ of 1.2 ; net reproductive rate $\left(R_{0}\right)$ of 24.6; generation duration $(T)$ of 18.6 and, innate capacity for increase in number $\left(r_{m}\right)$ of 0.17 . For mated females, the values were as follows: 1.1 for $(\lambda), 11.5$ for $\left(R_{0}\right), 19.7$ for $(T)$ and 0.12 for $\left(r_{m}\right)$ (Table 3).

The net reproductive rate $\left(R_{0}\right)$ found on gerbera for non-mated females are different from those reported by Silva et al. (1985) for this same species on cotton, from 34.4 to 54.5 . The biology of the mite may have been influenced by the host plant and these suggest the importance of studying T. urticae on other ornamental species. The same situation may have influenced the mean generation time (T), where Silva et al. (1985) found values between 22.2 and 24.9 days on cotton and beans, respectively, higher values than those found in this study.

Acording to Gallo et al. (2002) the two spotted mite, T. urticae, feeds on a large number of plant species such as cotton, strawberry, rose, tomato, beans, soybeans, peach, among others, evidence of a potential pest for Brazil. Gerbera is a good host plant for this tetranychid, specially when cultivated in protected environments. Edaphoclimatic conditions, nutritional aspects and population density variations influence mite behaviour. Thus, more research is needed to evaluate T. urticae biology on several host plants, especially on ornamentals. Environmental diversity may explain variations revealed by several authors, like the findings reported by Laing (1969) for the sex ratio of mated females (0.74), slightly higher than what was reported in this study.

The values obtained through the life table in this work are important in the evaluation of population growth of this species on gerbera, favouring comparisons with other plant species of economic expression in the country which also host this mite.

Acknowledgements - To the "Fundo de Amparo à Pesquisa do Estado do Maranhão - FAPEMA" and "Conselho Nacional de Desenvolvimento Científico e Tecnológico - CNPq" for the scholarships granted.

\section{References}

CARNE-CAVAGNARO, VL., ROBB, KL., TJOSVOLD, SA., NEWMAN, JP. and PARRELLA, MP., 2005. Demonstrating reduced-risk practices for control of important pests of Gerbera jamesonii grown as cut flower. Bulletin IOBC/WPRS, vol. 28, no. 1 , p. 35-38.

CHAHINE, H. and MICHELAKIS, S., 1994. Bioecological control studies on Tetranychus urticae Koch. (ACARINA, TETRANYCHIDAE). Bulletin IOBC/WPRS, vol. 17, no. 1, p. 121-124.

GALLO, D., NAKANO, O., SILVEIRA-NETO, S., CARVALHO, RPL., BAPTISTA, GC., BERTI-FILHO, E., PARRA, JRP., ZUCCHI, RA., ALVES, SB., VENDRAMIM, JD., MARCHINI, LC., LOPES, JRS. and OMOTO, C., 2002. Entomologia Agrícola. Piracicaba: FEALQ. 920 p.

GARCÍA-MARÍ, F. \& GONZALÉZ-ZAMORA, JE., 1999. Biological control of Tetranychus urticae (Acari: Tetranychidae) with naturally occurring predators in strawberry plantings in Valencia, Spain. Experimental and Applied Acarology, vol. 23, no. $6,487-495$.

Instituto Brasileiro de Floricultura - IBRAFLOR, 2006. Boletim IBRAFLOR. Campinas: IBRAFLOR. 60 p.

KARLIK, JF., GOODELL, PB. and OSTEEN, GW., 1995. Improved mite sampling may reduce acaricide use in roses. California Agriculture, vol. 49, no. 1-4, p. 38-40.

LAING, JE., 1969. Life history and life table of Tetranychus urticae Koch. Acarologia, vol. 11, no. 1, p. 32-42.

LORENZI, H. and SOUZA, HM., 2000. Plantas ornamentais no Brasil: arbustivas, herbáceas e trepadeiras. São Paulo: Instituto Plantarum de Estudos da Flora LTDA. 1088 p.

REIS, PR., SILVA, EA. and ZACARIAS, MS., 2005. Controle biológico de ácaros em cultivos protegidos. Informe Agropecuário, vol. 26, no. 225, p. 58-67.

RORIZ, A. and CUNHA, AP., 1998. Enciclopédia 1001 plantas e flores. São Paulo: Europa. 258 p.

SHIH, CIT., POE, SL. and CROMROY, HL., 1976. Biology, life table, and intrinsic rate of increase of Tetranychus urticae. Annals of Entomological Society of America, vol. 69, no. 2, p. $362-364$

SILVA, MA., PARRA, JRP. and CHIAVEGATO, LG., 1985. Biologia comparada de Tetranychus urticae em cultivares de algodoeiro. II. Tabela de vida de fertilidade. Pesquisa Agropecuária Brasileira, vol. 20, no. 9, p. 1015-1019.

SILVEIRA-NETO, S., NAKANO, O., BARBIN, D. and VILLANOVA, NA., 1976. Manual de ecologia dos insetos. São Paulo, Editora Ceres. 419 p.

VRIE, M. Van de, MCMURTRY, JA. and HUFFAKER, CB., 1972. Ecology of tetranychid mites and their enemies - a review - III: biology, ecology, and pest status, and host-plant relations of tetranychids. Hilgardia, vol. 41, no. 13, p. 343-432. 